\begin{tabular}{r}
\hline \hline $811.163 .411^{\prime} 374$ \\
$811.163 .41: 81^{\prime} 42$ \\
$811.163 .411^{\prime 271}$ \\
https://doi.org/10.18485/msc.2018.47.1.ch10
\end{tabular}

Бојана С. МИЛОСАВљЕВИЋ ${ }^{*}$

Оригинални научни рад

Универзитет у Београду

Примљен: 31. 11. 2017.

Учитељски факултет

Прихваћен: 27. 12. 2017.

\title{
ПЕРФОРМАТИВНЕ ФОРМЕ ГОВОРНЕ ЕТИКЕЦИЈЕ У ЛЕКСИКОГРАФСКОМ ОПИСУ**
}

\begin{abstract}
У раду се са лексикографског становишта описују перформативне форме говорне етикеције - форме које садрже перформативне глаголе као експлицитне показатеље говорног чина, нпр. захваљујем (ти/Вам)(се) - форма захваљивања, извињавам (ти/Вам) се - форма извињења, молим (те/Вас), преклињам (те/Вас) - форме за исказивање молбе, поздрављам (те/Вас) - поздравна форма, (покр.) сажсаљевам (случај), одн. саучествујем у болу - форме за исказивање саучешћа, честитам (ти/Вам) - форма честитања, благодарим (ти/Вам) - архаична форма захваљивања. На првом месту пажња се обраћа на то да ли се оне региструју у речницима (Речник САНУ, шестотомни Речник МС и једнотомни Речник МC), и ако се региструју, на који начин се то чини будући да су у питању облици перформативних глагола. Сходно томе разматрају се и два могућа модела њиховог бележења у речницима, зависно од тога да ли се на њих гледа само као на облике перформативне употребе глагола или као на изразе, фразе које у језику имају статус дискурсних формула.

Кључне речи: (перформативне) форме говорне етикеције, перформативни глаголи, квалификатор перформатив, дискурсне формуле, лексикографски метајезик, Речник CAHY.
\end{abstract}

У систему лексичких јединица, форме говорне етикеције (поздрави, форме ословљавања, захваљивања и др.), иако су бројно ограничене, представљају посебан и карактеристичан лексички слој. Њихова посебност и специфичност огледа се на формалном и на семантичко-прагматичком плану. На формалном плану карактеристичним их чини устаљени облик. На семантичко-прагматичком плану специфичне су по томе што се у комуникацији

\footnotetext{
*bojana.303@gmail.com

** Истраживање у раду спроводи се у оквиру пројекта бр. 178009 Лингвистичка истраживања савременог српског језика и израда Речника српскохрватског књижевног и народног језика $C A H У$, који у целини финансира Министарство просвете и науке, а изводи се у Институту за српски језик САНУ.
} 
ситуационо појављују сходно медијуму комуникације (писана или усмена), сходно односу међу саговорницима (дистанциран или недистанциран) и сходно стилу комуникације (формалан или неформалан). Отуда се лингвистичка истраживања ових лексичких јединица не могу ослањати само на лексичко-семантичка испитивања, већ се морају базирати на комуникативно-прагматичким и функционалностилским истраживањама. У првом плану тих истраживања налази се управо њихова употреба у језику, а значење се посматра с аспекта говорникове намере.

То је и разлог због чега домаће граматике традиционалног приступа не помињу овај тип језичких јединица будући да се оне у опису језичких јединица држе махом њихове формалне стране и синтаксичке семантике. Таква ситуација са граматичким описом ових лексичких јединица разумљива је будући да су дескриптивне граматике пре свега у служби стицања граматичке компетенције, а у доста мањој мери у служби стицања прагматичке компетенције. Изузетак би у том смислу била Граматика П. Мразовић и 3. Вукадиновић, намењена странцима, односно учењу српског језика као страног, која, с обзиром на своју сврху, у граматички опис укључује и прагматички, комуникативни план, те се о перформативним формама и уопште о формама говорне етикеције говори у оквиру говорних чинова и њихових изражајних могућности (уп. Мразовић и Вукадиновић 2009: 677-724). И новије граматике посвећују пажњу прагматичком плану језика, па говоре о комуникативним функцијама језика и о говорним чиновима (уп. Поповић Људ. 2005: 983-1059).

Дескриптивни речници српског језика, за разлику од наших традиционалних граматика, иако се заснивају на њима, представљају форме говорне етикеције релативно добро изграђеним метајезиком (Милосављевић 2008: 149). Но, без обзира на то, метајезик наше дескриптивне лексикографије потребно је додатно испитивати и изучавати како би се лексикографски поступци и начини унапредили и учинили експлицитнијим у семантичким назначавањима и у техничким обележавањима оних језичких феномена који су у фокусу новијих лингвистичких истраживања. Један од тих феномена који тражи адекватније и експлицитније представљање у лексикографским описима, а тиче се и говорне етикеције, јесте и лексичко-граматичка категорија перформативности. У центру те категорије налазе се перформативни глаголи чије је основно семантичко-прагматичко обележје еквиакционалност, тј. говорење је чињење.

Стога се овом приликом са лексикографског становишта посматрају перформативне форме говорне етикеције - форме које садрже перформативне глаголе као експлицитне показатеље говорног чина - захваљьјем ( (се) - форма захваљивања, извињавам (ти/Вам) се - форма извињења, молим $(\mathrm{me} / \mathrm{Bac})$ - форма за исказивање молбе, поздрављам (me/Bac) - поздравна форма, (покр.) сажаљевам (случај), одн. саучествујем у болу - форме за исказивање саучешћа, честитам (ти/Вам) - форма честитања, благодарим (ти) Вам) - форма захваљивања архаичног призвука. Један од циљева посматрања је описати њихов статус у нашим дескриптивним речницима (Речник 
САНУ, шестотомни Речник MC и једнотомни Речник MC), где се на првом месту пажња обраћа на то да ли се ове форме региструју у речницима, и ако се региструју, на који начин се то чини будући да су у питању перформативни облици глагола, док се у раду у мањој мери обраћа пажња на то како се оне дефинишу, односно како се семантички описују. Други циљ је и предложити начин њиховог бележења у речнику дескриптивног типа имајући у виду, с једне стране, језичку природу ових форми и, с друге стране, њихов комуникативни значај.

Ево шта можемо рећи о томе какав статус имају наведене форме говорне етикеције у нашим описним речницима.

1) Ни у једном речнику се ове форме не издвајају као одреднице. Разлог је јасан. У питању су презентски облици за 1. лице, а морфолошко-синтаксички облици речи не успостављају се као одреднице осим ако нису лексикализовани. Иако се у речницима српског језика ове форме не дају као одреднице, неке од њих се јављају у опису других форми говорне етикеције. Тако се форма за захваљивање хвала ти у речницима дефинише перформативом захваљујем ти (РМС и РСЈ, под хвала изр). У једнотомном Речнику МС перформативом преклињем те дефинише се експресивни израз кумим те богом, којим се у комуникацији интензивира молба (РСЈ, под кумити). У шестотомном Речнику МС форма жао ми је, којом се изражава жаљење, извињење, дефинише се, између осталог, и као жалим, сажаљевам (некоza, нешто) (РМС, под жао). Дакле, у наведеним примерима перформативни облици јављају се у семантичким дефиницијама датих израза као њихови синоними, добијајући тако статус лексикализованих облика.

2) Поменути израз кумим те богом занимљив је и с друге стране. У једнотомном Речнику МС овај израз се издваја као посебан, и то у овом облику - дакле, у облику перформатива. У шестотомном Речнику МС пак издваја се у инфинитивном облику као кумити богом, док се у Речнику САНУ ова форма уопште не издваја засебно, али се значење гл. кумити 'усрдно молити; заклињући молити, преклињати' илуструје примерима (Л. Лазаревића и Б. Нушића) у којима је овај израз дат у перформативном облику. Међу лексикографима очигледно постоји двоумљење око тога како ову дискурну формулу из реда перформативних форми успоставити у речнику - да ли у инфинитивном или у перформативном облику.

3) Што се тиче навођења примера којима се илуструје перформативна употреба глагола, може се рећи да се у Речнику САНУ они спорадично наводе. Принцип којег се лексикографи првенствено држе при одабирању примера јесте тај да се бележе примери од добрих писаца и да буду из разних раздобља и разних крајева да би се што јасније и што потпуније показало значење, као и временска и просторна употреба речи. Води се рачуна и о томе да примери потврђују и различите синтагматске и синтаксичке везе међу речима (нпр. колокације, рекција и др.). Отуда су се код глагола кумити у Речнику САНУ нашли примери Л. Лазаревића и Б. Нушића, а код глагола захваљивати (се) као примери његове перформативне употребе нашли су се примери из Вуковог дела и из Конавала (и то у оба примера дијал. облик 
захваљивам). Међутим, примећујемо да се у Речнику САНУ глагол извињавати се у значењу 'молити да се нешто не узме за зло, тражити опроштај; оправдавати се, изговарати се, испричавати се' илуструје великим бројем примера - чак једанаест примера је дато, али ниједан не илуструје перформативну употребу овог глагола.

4) У систему српске говорне етикеције перформативно се употребљавају и перифрастичне конструкције, и то обично с глаголом исказивати, изражавати, изјављивати (нпр. изражавам жаљење, изражавам захвалност и др.), односно с глаголом обраћати се (обраћам Вам се с молбом), с глаголом упућивати (упућујем саучешће, упућујем честитике). У речницима се пак ове перифрастичне конструкције не региструју као форме устаљеног облика формулаичког значења и ситуационе употребе. Изузетак чини изјавити, исказати саучешће која се у инфинитивном облику као израз издваја у Речнику МС (РМС, под саучешће).

Према ономе што налазимо у нашој лексикографској пракси у вези с представљањем форми говорне етикеције које садрже перформативне глаголе, сматрамо да је потребно наћи систематско решење у начину њиховог регистровања, описивања и илустровања. Међутим, поставља се питање да ли на њих гледати само као на перформативно употребљене глаголе или као на идиоматизоване перформативне облике тих глагола који на плану комуникације функционишу као дискурсне формуле - као типски искази који у комуникацији упућују на отпочињање и на завршавање разговора, на тему разговора, на медијум комуникације и на друге елементе комуникације. У зависности од тога како се гледа на њих, и њихово бележење и представљање у речницима ће се битно разликовати. Ево и на који начин.

Ако се форме захваљујем (ти/Вам) се, извиьавам (ти/Вам) се, честитам $(m и / B a м)$ и др. виде само као перформативно употребљени глаголи захваљивати се, извиъавати се, честитати и др., онда се њихово лексикографско описивање не би умногоме разликовало од оног које је већ у литератури, домаћој и страној, дато као предлог за описивање свих глагола говорења који се могу перформативно употребљавати.

Наиме, Ј. Д. Апресјан је међу првима указао на то да се у речницима код сваке глаголске лексеме, односно глаголског израза, који се у неком од својих значења могу перформативно употребити, то и назначи. Свака таква глаголска лексема мора се најпре описати с лексичкосемантичког аспекта, а потом, у посебном делу речничког чланка, у тзв. прагматичкој зони чланка, представити и као перформатив. У ту сврху, по њему, користио би се квалификатор са значењем перформатив, одн. перформативност - перформ. (Апресјан 1995: 214). Такав став је у складу са његовим залагањем за интегралним описом лексичких јединица, под којим се подразумева системско описивање лексике, односно израђивање лексикографских портрета лексема с циљем да се представе заједничка својства лексеме с другим лексемама (унификација), али и она својства по којима се дата лексема разликује од друге лексеме (индивидуализација). Речнички чланак би тако чинило више зона описа, а једна од тих зона је и зона прагматике (Апресјан 1995: 135-153; Ристић/Радић Дугоњић 1999: 29, Ристић 1999: 128). 
Пратећи Апресјанова залагања у том правцу, у нашој лингвистичкој средини о перформативним глаголима из угла лексикографије писао је Д. Војводић. На материјалу српског, руског и пољског језика, Војводић је разматрао основне типове синтаксичко-семантичке валентности перформативних глагола. Овај аутор је истакао да се обележје перформативности, без обзира на тип валентности глагола, мора одразити у лексикографском опису перформативног глагола (Војводић 1999: 89). Перформативна употреба глагола у речницима општега типа, по њему, треба да се издвоји као посебно значење у оквиру семантичке структуре глагола. Да би на конкретном примеру то и показао, Д. Војводић је из једног речника савременог руског језика ${ }^{1}$ навео опис глагола просить, који је он, за потребе илустрације, допунио описом перформативне употребе овог глагола. Погледајмо и како:

ПРОСИТЬ, прошу, просишь; прошенный; несов. 1. о ком-о чем, кого-чего, кого-что (с конкретн. сущ. разг.), с неопр. или с союзом , чтобы”. Обращаться к кому-н. с просьбой о чем.-н. П. о помощи (помощ, помочь, чтобы помогли). П. пощзады. Сын просит купить велосипед или просит велосипед. [...] 7. перформ. (употр. только 1. л. ед. ч. нас. вр.) Прошу тебя покинуть зал. (к 1. знач.).

У предложеном моделу, као што се примећује, Д. Војводић је перформативну употребу глагола у његовој семантичкој структури издвојио као последње значење, седмо. На њега је указао на два начина: и квалификатором перформ. и граматичким описом, тј. назнаком датом у загради да се овај глагол као перформатив употребљава само у 1. л. једн. презента. Перформативну употребу, као што се из модела види, није дефинисао, већ ју је само потврдио одговарајућим примером, и упућивањем на прво значење глагола просить повезао ју је са његовим примарним значењем - 'обраћати се некоме са молбом за нешто'2.

У којој мери се предложени модел може прихватити и у нашем случају?

Предложеног квалификатора перформ. са значењем 'перформатив, перформативност' у лексикографском метајезику наше дескриптивне лексикографије још увек нема. Сматрамо да би се његовим увођењем у систем лексикографских ознака технички, а и семантички обухватили сви видови перформативне парадигме глагола будући да се под перформативном парадигмом глагола не подразумева само његова експлицитно-перформативна формула - тј. облик 1. лица једн. апсолутног презента (нпр. Молим те/Вас..., Поздрављам те/Bac). Подразумевају се и његови транспоновани облици у којима се значење глагола везује за говорно лице, али није обавезно исказано првим лицем једн. апсолутног презента (нпр. Поздравља те, Весна (у потпису), Моли те твоја мајка или Буди ми поздрављена, Весна (у потпису)), а главна одлика им је еквиакционалност. Такође, квалификатором са значењем

${ }^{1}$ Ожегов С. И. Словарь русского языка, 23-е изд., испр. (под. ред. Н. Ю. Шведовой), М.: Русский язык, 1990.

${ }^{2}$ Д. Војводић у свом раду предлаже и лескикографски модел описа перформативних глагола у речницима посебних намена, пре свега у рекцијском речнику глагола, који ми овде нећемо разматрати будући да нас занима лексикографски опис перформатива у општем дескриптивном речнику. 
перформатив, одн. перформативност обухватили би се и сви други глаголски облици који илокутивно могу заменити експлицитни перформатив, нпр. потенцијал и футур I (Молила бих те..., Молићу Вас ...), којим се уноси допунски тон учтивости и др. (Поповић 2005: 984, 1003).

Међутим, увођење квалификатора перформ. у лексикографски метајезик наше традиционалне лексикографије наилази на извесне тешкоће. Прво, сам термин перформатив је страног порекла и нема одговарајући домаћи еквивалент у нашој лингвистичкој терминологији те би стога одступао од домаће лексикографске праксе. У нашим општим дескриптивним речницима се пак настоји да квалификатори граматичких термина и термина уопште буду домаће речи. Примера ради, за обележавање глаголског вида користе се квалификатори свр.(шени) и несвр.(щени), а не ознаке латинског порекла са значењем имперфективност, односно перфективност. Додуше, има и оних ознака које су страног порекла, нпр. неол.(огизам), али таквим ознакама се прибегава онда када у лингвистичкој терминологији нема одговарајуће домаће замене, а поред тога термин страног порекла је познат и изван науке. Предност се ипак даје домаћим ознакама, будући да се има у виду шири круг корисника речника и њихово скромно лингвистичко знање, па је потребно да граматичке и друге информације које се дају у речницима читаоцима буду и разумљиве. Друго, увођење квалификатора перформ. у лексикографски метајезик наше опште дескриптивне лексикографије захтевао би и прагматичку дефиницију глагола, која би се морала издвојити као посебно (под)значење, а тиме би се у великој мери одступило од дасадашњег начина лексичкосемантичког описа глагола. Но, квалификатор перформ. свакако би био неопходан у речницима специјализованих намена, пре свега у оним синтаксичког и прагматичког карактера (нпр. у рекцијском речнику, у речнику говорне етикеције и др.). А када је у питању општи описни речник тезаурусног типа, какав је Речник САНУ, по нашем мишљењу, компромисно решење огледало би се у следећем.

Перформативност глагола, као његово синтаксичко-семантичко својство, уместо квалификатора перформ. могло би се описно представити формулацијом - често у 1. л. обично једнине, датом у глоси испред значења, где би се перформативност глагола обавезно потврђивала одговарајућим примерима. У глосама би се нашле и информације о рекцији глагола и о другим синтаксичким условима под којима се остварује дата употреба глагола. Такво лексикографско решење није непознато нашој лексикографској пракси. Налазимо га у Речнику САНУ код глагола молити, тачније код његовог тзв. окамењеног перформативног облика молим те/Bac, који у комуникацији, зависно од ситуације, остварује различита комуникативно-прагматичка значења:

3. (у 1. л. најчешће јд., обично у непотпуним или елиптичним реченицама) а. учтиво захтевати (нешто), позивати, предлагати, да се нешто учини. - Тишину молим (Змај). б. $у$ учтивом обраћању, у ословљавању. - Молим, молим госпон докторе (В. Петровић). в. са избледелим значењем, у чуђењу (са узвичном интонацијом). - Гле, молим те, овим се мастило скида с перета (К. Руварац). г. са упитном интонацијом, када се показује да се саговорникове речи нису добро чуле или када се очекују даље саговорникове речи. - Хоћу нешто да ти кажем. - Молим? (Ред.) (РСАНУ, под молити). 
По узору на ово решење, у општем дескриптивном речнику перформативност глагола из домена говорне етикеције захављивати (се), извињавати ce, честитати, поздрављати и др. назначавала би се на предложени начин и илустровала примерима који то потврђују; дакле, поред примера који потврђују дескриптивну употребу глагола, нашли би се и они који потврђују перформативну употребу. Глаголи захваљивати (се), поздрављати и честитати, сходно овом предлогу, описивали би се овако:

захваљивати [...] несвр. І. (често у 1. л. обично јд.) 1. (без допуне, некоме, некоме на нечему, некоме за нешто) исказивати, изражавати захвалност, одавати признање. - (1) За успешно лечење мајке захваљивао је свим лекарима. (2) Захваљујем Вам на указаном поверењу. (3) Изволите. - Ох, захваљујем!

2. (на нечему) учтиво одбијати понућено. - Кафу и воду ћу узети, а на осталоме захваљујем.

II. ce (често у 1. л. обично јд.) в. захваљивати (I). - (1) Снаха се захваљивала на помоћи. (2) Је ли по вољи мало хладна печења? Вина? Он се захваљивао. - Не могу да једем. (3) Захваљујем Вам се на поклону.

поздрављати [...] несвр. І. (често у 1. л. обично јд.) (некога) 1. говорити, чинити некоме поздрав (у обраћању већем броју лица при сусрету или растанку, као заврини поздрав у писаном обраћању). - (1) Учитељ најпре поздравља ђаке, па их тек онда прозива. (2) Поздрављам све присутне и желим Вам успешан рад. (3) Мила моја ... поздрављам те и с нестрпљењем ишчекујем твоје писмо.

честитати [...] свр. и несвр. (често у 1 . л. обично јд.) (без допуне, некоме, некоме нешто, некоме на нечему) изразити, изражсавати осећање задовољства, среће и сл. поводом каквог радосног или значајног догађаја и (за)желети срећу. - (1) На дан свадбе честита му само жицом, и то беше све. (2) Честитам ти рођење кћерке.

Овај начин лексикографског представљања перформативности био би примењив и у опису других глагола који се могу перформативно употребљавати (нпр. клети се, гарантовати, обећавати, слагати се), не само у опису оних из реда говорне етикеције, које смо ми овде узели у разматрање.

Ако се пак на форме захваљујем (ти/Вам) се, извиьавам (ти/Вам) се, честитам (ти/Вам) и др. гледа као на идиоматизоване облике перформативно употребљених глагола који на формалном, на семантичком и на комуникативно-прагматичком плану функционишу као дискурсне формуле, требало би их у речнику третирати као и све друге дискурсне формуле. У том случају би се издвајале као пододреднице, тј. као засебне лексичке јединице у делу где се бележе изрази, фразе. Добиле би тако статус идиома и могућност да се дефинишу сходно својој употреби, тј. у складу са својим прагматичким значењем, где би се у дефиницији истицали елементи важни за комуникативну ситуацију (формални или неформални стил, однос говорника, медијум комуникације, остварени говорни чин и др.). Отуда би се језичке форме из реда говорне етикеције захваљујем (ти/Вам) (се), поздрављам (те/Вас), честиmaм (mu/Baм) и др. у речнику српског језика код датог глагола представљале као изрази, с одговарајућом прагматичком дефиницијом и с илустративним примерима. За модел дајемо описе форми захваљујем (ти/Вам) (се), поздрављам (те/Вас) и честитам (ти/Вам):

захваљујем(о) (ти/Вам итд.) (се) а. уобичајена формула захваљивања у писаном и усменом обраћању. - (1) Захваљујем Вам на указаном поверењу. (2) Изволите. - Ох, за- 
хваљујем! (3) Захваљујем Вам се на поклону. б. формула којом се на учтив начин одбија каква понуда. - Кафу и воду ћу узети, а на осталоме захваљујем (као израз код гл. захваљивати (се)).

поздрављам(о) (те/ Вас итд.) (пуно) поздрав у усменом обраћағу већем броју лиияа при сусрету или растанку, често као завршни поздрав у писаном обраћању. - (1) Поздрављам све присутне и желим Вам успешан рад. (2) Мила моја ... поздрављам те пуно и с нестрпљењем ишчекујем твоје писмо (као израз код гл. поздрављати).

честитам(о) (ти/Вам итд.) (искрено, од срца и сл.) уобичајена формула честитања у писаном и усменом обраћању. - (1) Честитамо вам рођење кћерке. (2) Од срца ти честитам! (као израз код гл. честитати).

Ово лексикографско решење отвара могућност да се и перифрастичне форме говорне етикеције, које се такође перформативно употребљавају, региструју као изрази код именица које садрже. На пример, форма честитања ynyћyjем честитке која се јавља у формалној комуникацији, писаној и усменој, у речнику би се као израз код именице честитка представила на следећи начин:

упућујем(о) (искрене, најискреније и др.) честитке (некоме) формула честитања у званичном, обично писаном обраћању. - У име Владе Републике Србије и у своје лично име упућујем вам најискреније честитке поводом 6. августа, Дана рудара Србије.

По сличном моделу би се могле описати и форме изражавам захвалност и обраћам Вам се са молбом:

изражавам(о) (исказујем(о)) (искрену, дубоку) захвалност формула захваљиваға y званичном писменом или усменом обраћаюу. - Изражавамо искрену захвалност Великој Британији што је одговорила на наш позив да помогне у спасавању морнара (као израз код им. захвалност).

обраћам(о) Вам се с молбом формула у званичном писменом обраћаьу меродавној особи, органу, установи и сл. када се тражи решење, одобрење неког захтева и сл. - Обраћам Вам се с молбом да ми се у складу с новим Правилником о издавачкој делатности исплати ауторски хонорар (као израз код им. молба).

Оваквим лексикографским описом на бољи начин би се представила комуникативна природа ових форми, а то је њихов формулаички израз и ситуациона употреба. С друге стране, као дискурсне формуле, биле би видљивије у речничком тексту и могле би се и нормирати с обзиром на сферу употребе. На пример, форма обраћам Вам се с молбом маркирала би се као форма карактеристична за административни стил и др.

И овај начин лексикографског описа перформативних форми говорне етикеције ослањао би се на нашу речничку праксу. Формулаички израз кумим те богом, као што смо раније у тексту навели, у једнотомном Речнику МC се представља у перформативном, а не у инфинитивном облику. Иначе, једнотомни Речник МС, за разлику од других речника, бележи и већи број дискурсних формула, показујући тако склоност ка томе да из комуникације идиоматизоване језичке јединице, фразе бележи засебно као лексикализоване облике. У том смислу и видимо оправданост оваквог представљања перформативних форми говорне етикеције.

Несумњиво је да се и једним и другим предложеним лексикографским моделом обраде перформативних форми говорне етикеције семантичка 
структура речи усложњава будући да се у граматичком опису речи даје већи број синтаксичких информација, издвајају се нови изрази, нова значења речи, а и њихова употреба се нормира с обзиром на то да се могу давати и прескриптивна правила употребе у језику. Тиме се свакако превазилази минималистичка концепција у обради лексичких јединица и чини се значајан напредак на прелазу од традиционалног приступа језичким феноменима ка савременијим, где се прате актуелна сазнања и новије тенденције како у областима лексикографије и лексикологије тако и у областима других лингвистичких дисциплина.

\section{ЛИТЕРАТУРА}

Апресјан 1995: Ю. Д. Апресян, Изабранные труды, том II: Интегральное описание языка и системная лексикография, Москва: Школа „Языки русской культуры".

Војводић 1999: Д. Войводич, О валентности перформативных глаголов в славянских языках, Зборник Матище српске за славистику, 56-57, 71-94.

Милосављевић 2008: Б. Милосаљевић, Лексикографски поступци при представљању форми говорне етикеције у српским дескриптивним речницима, y: (ур. Б. Остојић), Седми лингвистички скуп „Бошковићеви дани”, Подгорица: ЦАНУ, 137-151.

Мразовић/Вукадиновић 2009: P. Mrazović, Z. Vukadinović, Gramatika srpskog jezika za strance, Sremski Karlovci: Izdavačka knjižarnica Zorana Stojanovića.

Поповић 2005: Људ. Поповић, Комуникативне функције просте реченице, $y$ : Синтакса савременога српског језика. Проста реченица, (ред. М. Ивић), Београд: Институт за српски језик САНУ, Београдска књига-Нови Сад: Матица српска, 983-1059.

Речник МС: Речник српскохрватскога књижевног језика, I-VI, Нови Сад: Матица српске 1967-1976.

Речник САНУ: Речник српскохрватског књижевног и народног језика, IXIX, Београд: Институт за српски језик САНУ, 1959-.

Ристић 1999: С. Ристић, Партикула само у светлу теорије интегралног описа, y: С. Ристић, М. Радић-Дугоњић, Реч. Смисао. Сазнање, Београд: Филолошки факултет, 128-139.

Ристић/Радић Дугоњић 1999: С. Ристић, М. Радић-Дугоњић, Интегрални опис лексичких јединица и системска лексикографија, y: С. Ристић, М. Радић-Дугоњић, Реч. Смисао. Сазнање, Београд: Филолошки факултет, 28-32.

PCJ: Речник српскога језика, Нови Сад: Матица српска, 2007. 


\title{
THE LEXICOGRAPHIC TREATMENT OF SERBIAN POLITE FORMS WITH PERFORMATIVE VERBS
}

\begin{abstract}
Summary
In this article we have analyzed lexicographic treatment of Serbian polite forms with performative verbs, such as: захваљујем (ти/Вам)(се) - the gratitude form, извињавам (ти/Вам) се - the form of apology, молим (mе/Ваc) - the form of requests, поздрављам (me/Bac) - the greeting form, сажаљевам (случај), саучествујем у болу - the forms of condolences, честитам (ти/Вам) - the form of congratulations. Our aim was to find a lexicographic model to represent them in descriptive dictionary of Serbian language. In our opinion, these performative forms could be described in two ways: 1) like verb lexical units marked by qualificator performativ and 2) like idiomatic lexical units as discourse formulas.

Key words: polite forms with performative verbs, performative verbs, qualificator performativ, discourse formulas, lexicographic metalanguage, descriptive dictionary.
\end{abstract}

